\title{
Prevalence and Intensity of Haemoproteus columbae in Three Species of Wild Doves from Brazil
}

\author{
Edson A Adriano $^{+}$, Nelson S Cordeiro \\ Departamento de Parasitologia, Instituto de Biologia, Universidade Estadual de Campinas, Caixa Postal 6.109, \\ 13083-970 Campinas, SP, Brasil
}

The prevalence and intensity of blood parasites in three species of wild doves were studied in the municipality of Junqueirópolis, in the western region of the State of São Paulo, Brazil. Three species of doves were surveyed: 331 specimens of Zenaida auriculata Des Murs, 1847, 62 specimens of Columbina talpacoti Temminck, 1811 and 57 specimens of Scardafella squammata Lesson, 1831. Haemoproteus columbae Kruse, 1890 was found in blood from all the doves species. The prevalence of this parasite was $100 \%$ in Z. auriculata, $51.6 \%$ in C. talpacoti and $19.3 \%$ in S. squammata. Specimens of Z. auriculata had a higher intensity of infection than the other doves species.

Key words: Haemoproteus columbae - Zenaida auriculata - Columbina talpacoti - Scardafella squammata wild doves - Hippoboscidae

Haemoproteids occur widely in avian populations. In columbids seven species of Haemoproteus were described: Haemoproteus columbae Kruze, 1890; Haemoproteus sacharovi Novy and MacNeal, 1904; Haemoproteus maccallumi Novy and MacNeal, 1904; Haemoproteus melopeliae Laveran and Petit, 1909; Haemoproteus turtur Covaledo Ortega and Gallego Berenguer, 1950; Haemoproteus perise Son, 1960 (Bennett \& Peirce, 1990). Levine (1961) regarded only $H$. columbae and $H$. sacharovi as distinct, and the remaining names were considered as synonyms of $H$. columbae. Baker (1966) described H. palumbis from Columba palumbis palumbis Linnaeus, 1758, and also questioned the validity of some of these species. Bennett and Peirce (1990), in a taxonomic review of the haemoproteids parasites of columbids, proposed that only $H$. columbae and $H$. sacharovi are valid species.

Hippoboscids flies are incriminated vectors of Haemoproteus spp. of Columbiformes. Natural vectors of $H$. sacharovi are unknown (Bennett \& Peirce 1990), but Peseudolinchia maura (Bigot) transmitted this parasite in experimental infection (Huff 1932). Pseudolinchia canariensis (Macquart) was incriminated as the vector of $H$. columbae in Columba livia Gmelin, 1789 in nature (Klei \&

\footnotetext{
This study was supported by Capes.

${ }^{+}$Corresponding author. Fax: +55-19-289.3124. E-mail: andrian@unicamp.br

Received 12 May 2000

Accepted 18 October 2000
}

DeGiust 1975) and in experimental infection (Ahmed \& Mohammed 1977). Greiner (1975) pointed out Microlynchia pusilla (Speiser) and Stilbometopa podopostyla (Speiser) as potential vectors of $H$. sacharovi and $H$. macallumi in Zenaida macroura Linnaeus, 1758.

Despite the importance of columbids in wild and/or domestic bird populations and also the synanthropic character of some doves species, few workers have studied the prevalence and intensity of haemoparasites in these birds (Greiner 1970, 1975, Gutiérrez 1973, Klei \& DeGiusti 1975, Shamis \& Forrester 1977, Dias et al. 1984, Mandal 1990).

In this work, the prevalence and intensity of haemoproteids were evaluated in three species of wild doves, namely, Zenaida auriculata Des Murs, 1847, Columbina talpacoti Temminck, 1811 and Scardafella squammata Lesson, 1831.

\section{MATERIALS AND METHODS}

Adult specimens of $Z$. auriculata $(\mathrm{n}=331), C$. talpacoti $(\mathrm{n}=62)$ and $S$. squammata $(\mathrm{n}=57)$ were captured using gauze-traps (Ibama 1994) in the municipality of Junqueirópolis, in the western region of the State of São Paulo, Brazil (213'ㄴ, 51'31'W), between January and December 1998.

Blood samples for the preparation of blood smears were obtained from a brachial vein and the doves then tagged and released. The air-dried blood smears were subsequently fixed in absolute methanol and stained with Giemsa's solution. The slides were examined microscopically at a magnification of 1000x. Parasites were only counted in fields with a homogenous distribution of erythrocytes, which most frequently occurred in the tails of the smears. 
The number of parasitized cells in each smear was counted in 300 fields using a micrometer incorporated into the eyepiece. The area covered by a $1000 \mathrm{x}$ magnification corresponded to $3.6 \mathrm{~mm}^{2}$.

Based on previous estimations, 300 fields contained an average of 30,000 red blood cells (RBC). The parasite species was identified by comparison with haemoproteid parasites of columbids described in the literature (Bennett \& Peirce 1990). Linear dimensions were obtained as described by Bennett and Campbell (1972) using a Zeiss Photomicroscope Axioplan II and Image-Pro Lite 4.0 program (Media Cybernetics 1998). Areas were determined with the aid of a camera lucida and counting squares on a grid (Forrester et al. 1977). Measurements are expressed as means followed (in parentheses) by the standard deviation. The number of specimens is indicated by $\mathrm{N}$ and the Nuclear Displacement Ration by NDR. Photomicrographs were obtained using a Zeiss Standard microscope and Kodak TMAX 100 film.

A chi-square test was used to compare the prevalence of the parasite among dove species. Pearson's correlation coefficient was used to determine if there was a correlation between the level of parasitaemia and the ambient temperature when the doves were caught.

\section{RESULTS}

Haemoproteus columbae Kruse, 1890 (Figure) was the only hemoparasite found in blood smears of the doves examined. The prevalence of infection was $100 \%$ in Z. auriculata, $51.6 \%$ in $C$. talpacoti and $19.3 \%$ in S. squammata. This difference among the prevalence in dove species was significant $\left(\chi_{2}^{2}=280.20 ; \mathrm{p}<0.0001\right)$.

The intensity of the parasitaemia in $Z$. auriculata, was 1-806 infected cells per 30,000 $\mathrm{RBC}$, and $51.3 \%$ of the positive samples had a parasitaemia of 1-40 infected cells per 30,000 RBC. Parasitaemias of 41-100 infected cells per 30,000 RBC were recorded in $26.9 \%$ of the infected doves, and parasitaemias of 101-400 infected cells per $30,000 \mathrm{RBC}$ were found in $18.3 \%$ of the infected birds. Only $14.7 \%$ of the parasitized doves had more than 500 infected cells per 30,000 RBC. The highest parasitaemia (2.7\%) was observed in one specimen captured in August.

The intensity of parasitaemia in C. talpacoti was 1-30 infected cells per $30,000 \mathrm{RBC} ; 68.4 \%$ of the infected doves had parasitaemias of 1-6 infected cells per $30,000 \mathrm{RBC}, 26 \%$ of the parasitized doves had parasitaemias of 9-15 infected cells per 30,000 RBC, and only 5.2\% had more than 15 infected erythrocytes per $30,000 \mathrm{RBC}$. The highest parasitaemia $(0.1 \%)$ was observed in one specimen caught in February.

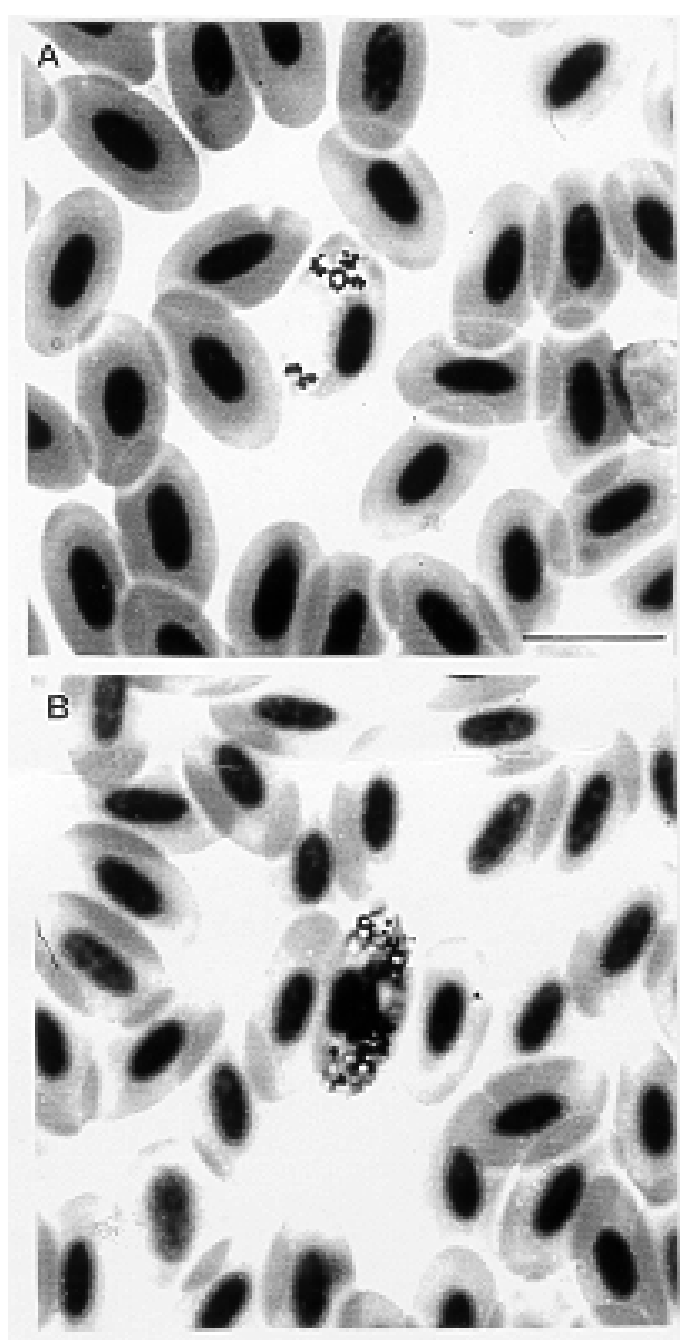

Photomicrographs of gametocytes of Haemoproteus columbae in erythrocytes of Zenaida auriculata. A: microgametocyte; B: macrogametocyte. $\mathrm{Bar}=10 \mu \mathrm{m}$

The intensity of parasitaemia in S. squammata was 1-9 infected cells per 30,000 RBC, and 81.8\% of the samples positives had parasitaemias 1-6 infected cells per 30,000 RBC. Parasitaemias involving more than seven infected cells per 30,000 RBC were recorded in only $18.2 \%$ of the parasitized doves. One specimen with highest parasitaemia $(0.03 \%)$ was captured in October.

The sex ratio of gametocytes was calculated for the three species of doves. It was $77.3 \%$ macrogametocytes for $Z$. auriculata, $81.9 \%$ for $C$. talpacoti and $76.9 \%$ for S. squammata.

There was no correlation between the level of parasitaemia and the variation in ambient temperature $(\mathrm{r}=0.017 ; \mathrm{p}=0.857)$.

During this study we observed the occurrence of two species of hippoboscids flies on doves: $P$. 
canariensis and Stilbometopa sp. The prevalence of $P$. canariensis was $58.4 \%$ in $Z$. auriculata, $36.5 \%$ in C. talpacoti and $33.6 \%$ in S. squammata. Stilbometopa sp. was found in $13.8 \%$ of the specimens of Z. auriculata, $7.2 \%$ of $C$. talpacoti and $8.4 \%$ of S. squammata.

\section{DISCUSSION}

This is the first study to compare the prevalence and intensity of $H$. columbae among dove species in the neotropical region. Z. auriculata had a higher prevalence and intensity of parasitism than C. talpacoti and S. squammata. The reasons for

TABLE

Morphometric parameters of gametocytes of Haemoproteus columbae of the three species of doves compared with $H$. columbae of Columba livia and H. sacharovi of Zenaida macroura according to Bennett and Peirce (1990)

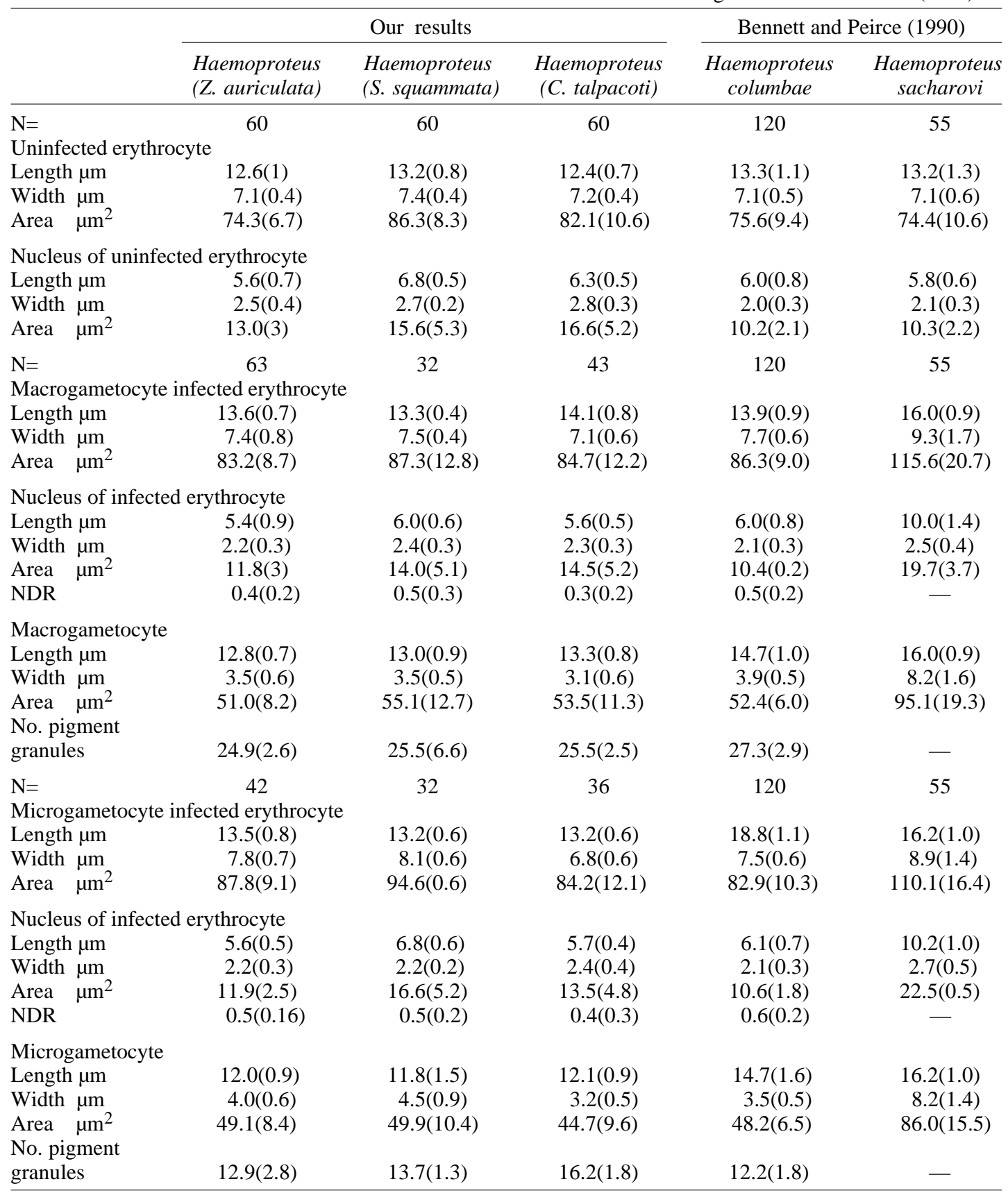

$\mathrm{N}$ : number of specimens; NDR: Nuclear Displacement Ration 
these differences are unknown but, as suggested White et al. (1978), may involve behavioral aspects or some physiological condition intrinsic to the species that may make the host more or less susceptible to the parasite.

From a behavioral point of view, C. talpacoti and $S$. squammata live in small flocks of a few individuals or are solitary (Hilty \& Brown 1986), whereas Z. auriculata lives in large flocks (Aguirre 1976, Donatelli et al. 1995) which facilitates the transmission of vectors and leads to a high prevalence and intensity of parasites. The higher prevalence of $H$. columbae in $C$. talpacoti than in $S$. squammata indicates that, in addition to behavioral aspects, physiological factors may also be involved in the parasite-host-vector relationship.

\section{ACKNOWLEDGEMENTS}

To Dr Angelo Pires do Prado (Departamento de Parasitologia, Instituto de Biologia, Universidade Estadual de Campinas), for the identification of the hippoboscids flies, to Dr Arício Xavier Linhares (Departamento de Parasitologia, Instituto de Biologia, Universidade Estadual de Campinas) for the help in statistics analysis and to Elizeu Adriano and Evair Adriano for collaboration in the field works.

\section{REFERENCES}

Aguirre AC 1976. Distribuição, Costumes e Extermínio $d a$ "avoante" Zenaida auriculata noronha Chubb, Ed. Academia Brasileira de Ciências, Rio de Janeiro, $35 \mathrm{pp}$.

Ahmed FE, Mohammed AH 1977. Schizogony in Haemoproteus columbae Kruse. J Protozool 24: 389-393.

Baker JR 1966. Haemoproteus palumbis sp. nov. (Sporozoa, Haemorporina) of the English wood-pigeon Columba p. palumbis. J Protozool 13: 515-519.

Bennett GF, Campbell AG 1972. Avian Haemoproteidae. I. Description of Haemoproteus fallisi n.sp. and a review of the haemoproteids of the family Turdidae. Can J Zool 50: 1269-1275.

Bennett GF, Peirce MA 1990. The haemoproteid parasites of the pigeons and doves (family Columbidae). J Nat Hist 24: 311-325.

Dias RMDS, Chieffi PP, Tolezano JE, Lupetti N 1984. Hemoparasitas de aves capturadas em duas regiões do Estado de São Paulo, Brasil. Rev Inst Adolfo Lutz. 44: 41-46.

Donatelli RJ, Andrela S, Santos R 1995. Uma metodologia para tentar minimizar o impacto de Zenaida auriculata (Aves: Columbiformes) sobre as áreas de cultivo de grãos na região sudeste do Estado de São Paulo. Salusvita 14: 21-29.

Forrester DJ, Greiner EC, Bennett GF, Kigaye MK 1977. Avian Haemoproteidae. 7. A review of the haemoproteids of the family Ciconiidae (storks) and descriptions of Haemoproteus brodkorbi sp. nov. and H. peircei sp. nov. Can J Zool 55: 1268-1274.

Greiner EC 1970. Epizootiological studies on Haemoproteus in Nebraska mourning doves (Zenaida macroura). J Parasitol 56: 187-188.

Greiner EC 1975. Prevalence and potential vectors of Haemoproteus in Nebraska mourning doves. $J$ Wildl Dis 11: 151-157.

Gutiérrez RJ 1973. Hematozoa from New Mexico mourning doves. J Parasitol 56: 932-933.

Hilty SL, Brown WL 1986. A Guide to the Birds of Colombia, Princeton University Press, New Jersey, $836 \mathrm{pp}$.

Huff CG 1932. Studies on Haemoproteus of mourning doves. Am J Hyg 16: 618-623.

Ibama 1994. Manual de Anilhamento de Aves Silvestres, 2 ed., Instituto Brasileiro do Meio Ambiente e dos Recursos Naturais Renováveis, Brasília, 148 pp.

Klei TS, DeGiusti DL 1975. Seasonal occurrence of Haemoproteus columbae Kruse and its vector Pseudolynchia canariensis Bequaert. J Wildl Dis 11: 130-135.

Levine ND 1961. Protozoan Parasites of Domestic Animals and Man, Burgess Publishing Company, Minneapolis, $406 \mathrm{pp}$.

Mandal FB 1990. Seasonal incidence of blood-inhabiting Haemoproteus columbae Kruse (Sporozoa: Haemoproteidae) in pigeons. Indian J Anim Hlth 29: 29-35.

Media Cybernetics 1998. Image-Pro Lite, The Proven Solution, Version 4.0 for Windows 95/Net/98.

Shamis JD, Forrester DJ 1977. Haematozoan parasites of mourning doves in Florida. $J$ Wildl Dis 13: 349355.

White EM, Greiner EC, Bennett GF, Herman CM 1978. Distribution of the hematozoa of Neotropical birds. Rev Biol Trop 26: 43-102. 